\title{
Illocution Gesture in Broca Aphasia Patients
}

\author{
Lilis Hartini*, Dadang Sudana, Wawan Gunawan \\ Linguistic Study Program, Universitas Pendidikan Indonesia Bandung, Indonesia \\ *Corresponding author. Email: Lilishartini90@ gmail.com
}

\begin{abstract}
Broca aphasia is a language disorder that occurs due to stroke in the left hemisphere of the brain and has an impact on impaired functional communication skills. People affected by Broca's aphasia will have difficulty in producing and expressing words in the form of verbal language so that the word production is limited. This article is a pragmatic study that aims to investigate the meaning of the illocutionary gesture of a Broca aphasia sufferer who has difficulty speaking in communicating. The theory used is the illocutionary speech act theory to show the illocutionary pressure produced by people with aphasia in conveying the meaning of their speech. The Illocutionary Stress Hint Tool is displayed by promising, warning, asking, saying, etc. as well as other mental states. This research is a case study of a single subject with Broca's aphasia, a 58-year-old man. The object of research is gestures and utterances conveyed by patients in communicating. Qualitative methods are used in processing data from observations that are recorded and described in the form of field notes. The results showed that the patient experienced verbal and nonverbal language difficulties, that is, the informant produced non-grammatical verbal utterances and unclear gestures. The language strategy that informants carry out is by gesturing the illocution of notifications, requests, complaints, wishes.
\end{abstract}

Keywords: Broca's aphasia, Gesture, Illocution, Pragmatics

\section{INTRODUCTION}

Whether we realize it or not, everyone needs contact with one another. The tool for making contact is language and the means is communication. For normal people, the language process will not experience obstacles because the language just slides from the utensil. However, for some people who have limitations in their minds, they will find it difficult in the communication process. One of them is experienced by people with aphasia.

Aphasia is a general term used to define a group of language disorders that occur after brain damage, which often affects the left hemisphere. Aphasia can affect both expressive and receptive aspects of communication including speaking, understanding, writing, reading, and gestures / gestures, so that aphasia is one of the most limiting cognitive deficits for patients because it causes functional disabilities and severe psychological pressure (Berthier, Dávila, García-Casares, \& Moreno-Torres, 2014, as cited in Purnomo, Sengkey, \& Damopolii, 2016)

The characteristics of each aphasia syndrome are characterized by the location of the affected lesions. Due to the fact that the nerve fibres in the brain are close together, the affinity syndrome is related to one another.
For example, in Broca's aphasia syndrome, which is aphasia which characterizes the defect in the language production area, it does not require the possibility of impaired understanding. Yet the area for understanding is in Wernicke. (Goodglas \& Kaplan, 1972)

This Broca area was the subject of research by researchers with the research subject of a Broca aphasia sufferer, who had been suffering from aphasia since 2003 due to a haemorrhagic stroke. This study focuses on illocutionary gestures that sufferers often do when making communication strategies. This strategy makes his speech partners often confused in understanding what he is saying. Patients always use body signals / gestures in carrying out any language activities. Gestures that are often done are moving your hands, nodding your head, shaking your head, or stamping your feet.

Illocution is a pragmatic theory of speech acts. Illocution is a speech act with a specific purpose between the speaker and the speech partner. The meaning expressed by the speaker in the illocution is the hidden meaning of a statement conveyed through words or sentences. According to Yule (1996), most of us don't just produce well-formed speeches without a purpose. We form speech with several functions in mind. This is the dimension of illocutionary action. Illocutionary acts 
are shown through the communicative emphasis of a speech. The most obvious means of indicating illocutionary stress is to use an illocutionary pressure gauge (APTI), which is a device used to explicitly express illocutionary action. This tool is represented by several conditions of speech from the speaker, such as we might speak a sentence to make a statement, offer, explanation, or other communicative purposes.

Thus, different speech acts can be used for the communicative purpose of the speaker in producing speech. Speakers usually expect their communicative intent to be understood by listeners. Speakers and listeners are usually helped by the circumstances around the speech environment. This kind of situation is called a speech event. It is the nature of speech events that determines the interpretation of a speech when presenting a special speech act. (Yule, 1996)

Based on observations, sufferers have difficulty retracting the words in their mind so that sufferers find it difficult to produce language when spoken. Gestures or gestures in the form of body movements are commonly done by sufferers in completing communication. Even the whole communication strategy is done using body movements. This informant's problem is interesting to study from a pragmatic point of view because pragmatics can reveal the interpretation of the informants' utterances using speech act theory. Illocutionary speech acts, to be precise. Therefore, to examine the speech acts conveyed by the informants, the researcher focused on APTI.

According to Yule (1996) pragmatics is interesting because it involves how people understand each other linguistically. This study requires us to understand other people and what is on their mind. In this case, pragmatics is used to reveal the contents of the informants' thoughts. In pragmatics, speech acts are the essence of communication. In connection with this, the problem discussed in this article is how the informant's strategy in communicating with speech partners. The goal is to describe and reveal the language errors of the informants in communicating.

\section{METHOD}

This research is a case study using a qualitative methodological design proposed by John W. Creswell (2019). Qualitative research is a method for exploring and understanding meanings ascribed to social or humanitarian problems. (Creswell, 2019, p. 4)

A case study is research by identifying a topic or question of interest, determining the appropriate unit to represent it, and determining what is known based on careful analysis of various sources of information about the "case" (Case studies: research identifies a topic or question of interest, determines appropriate unit to represent it, and defines what is known based on careful analysis of multiple sources of information about the "case"). Dawson and Algozzine (2006)

The consideration of researchers using qualitative methods is to produce descriptive data in the form of sentences uttered by the informant while suffering from aphasia Broca. This is based on observations over the past year, with the characteristics of the difficulty retaining the words in his mind due to lesions in the left hemisphere of his brain, namely the Broca area.

Researchers act as data collectors and as active instruments in collecting data in the field. The data collection technique is by observing the informants. Observations are recorded and described in field notes. Sources of data obtained from the results of observations in the field, observations, and the results of documentation studies.

The subject of the study was a 58-year-old man who had suffered a haemorrhagic stroke for 18 years and as a result of this stroke the patient had Broca's aphasia. Henceforth, research subjects are called informants. The communication tool used by the informants is Sundanese as the mother tongue. Sometimes, informants also use mixed codes in communicating. During the communication, the informant made body movements to complement the communication which he hoped the speech partner could understand. The object of research is the words or sentences uttered by the informant and gestures that complement the informants' intentions in communicating.

\section{FINDINGS AND DISCUSSION}

In observing the informants, the results show that the informants carry out communication purposes by emphasizing the illocution of speech with a strategy of adding gestures. The points in the following data indicate the silence made by the informant. Here are a few to get.

\subsection{Data:}

1. Rek ...itu...ieu

2. Tah...tah...

3. In: Tos...Astagfirullahal adzim Is: Belum, masih lama.

4. Teu...leungit nu pangalenganna.

5. Mah... aduh bangga.

6. In: Loba deui... iya...eh... Is: pakai mangkuk aja ya, biar ngga jatuh.

7. Is: jangan lupa pakai masker ya In: Heueuh ...eh... engke

8. In: Ieu aya...ieu...di...aya? Is: Pohon mangga?

9. In: ...mah...lap pel... 


\subsection{Analysis}

Data (1) was taken when the informant decided to sweep the house page by saying rek... itu... ieu... while carrying a broom in his left hand, pointing outside, wagging his right hand, then walking and opening the door. The meaning of the informant's words was "to sweep the house page." The informant emphasized the illocution of the speech by explaining the meaning, namely using a gesture wagging his hand, as if he wanted to clean something. One of the language barriers of the informants is seen when the process of retaining any word is not fast, so that the silence is filled with something, such as rek ... itu ... ieu ...

Meanwhile, data (2) was taken when the informant asked to buy snacks by saying tah ... tah ... while placing the index finger of the left hand in the mouth and then holding the left hand to the ear several times, like a person who was listening, and stood up from his seat to approach the mason. snacks. What he meant was that the informant said that "he wants to buy snacks" then took the snacks he liked. Apart from notifying and asking to buy snacks to the speech partners, the informant also took illocutionary actions, namely approaching the snack shop, asking for cakes by pointing to the food he liked.

Data (3) was taken when the informant suddenly came out of the room and said tos ... 'already' while pointing at the clock on the wall, then continued his utterance with Astagfirullahal adzim and holding his head, then raised his hands above his ears as demonstrating takbiratul ihram. The point of this speech is that the informant wants to know the time of arrival of the midday prayer. When he answered no, it was still a long time, the informant nodded and went back into the room. Here, the informant found it difficult to say the time for the dzuhur prayer, so the informant made a strategy by moving his hands above his ears. After his hopes were answered, the informant was satisfied because his speech could be understood by his speech partner. The illocutionary speech act conveyed by the informant was asking for information from the speech partner about prayer times.

The gesture that the informant took on the data (4) was getting up from his seat, walking to open the door, not taking a long time to return and pointing at the distant voice while stomping his feet, his face looked disappointed then the informant said: Teu ... leungit nu pangalenganna 'No ... lost the pangalengan.' During the illocutionary speech act, the informant intended to buy Pangalengan pure milk, but the merchant had already left. In this speech, the informant forgot the necessary word, namely pure milk, but the informant made a strategy by saying Pangalengan. The informant failed to look for the word, then the word pangalengan was used, which is one of the trademarks of pure milk in Bandung. A look of disappointment was seen on his face and an expression of anger was shown by stomping his feet for failing to buy whole milk. The speech act emphasized by the informant in his speech was to explain that the milkman had left, and the informant's disappointment was because he could not buy whole milk.

In data (5) the informant performs an illocutionary act by saying: Mah ... aduh bangga 'Mah ... oh it's difficult' while approaching the calendar, pointing to the south and leaving the house, continuing his speech by saying ka ditu ka dieu 'here and there'. This gesture can be understood by the speech partner because the speech partner already knows the informant's habits by guessing or interpreting with the intuition of the speech partner. Here the informant finds it difficult to retrace the word in his mind because of a defect in his left hemisphere. The language that the informant wanted to speak was already requested, but when he entered the speech tool, he encountered obstacles so that the informant made a communication strategy by approaching the calendar and pointing to the numbers on the calendar. It is hoped that the speech partners can understand the speech. The meaning of the informant in the speech was to want to know the day, whether it was Friday. Here the speech partner understands by interpreting the gesture of the informant who approaches the calendar, and the speech is marked. The purpose of the $k a$ ditu $k a$ dieu is the location of the mosque and the mosque, which because the informants often ask questions, the speech partner understands the meaning of what he said. Incidentally, there is a mosque near the house and in the west, some distance from the house there is a mosque. Just because of the defect in the Broca area, the way to point the direction is also wrong, which should be to the west instead to the south. The tools for emphasizing illocutionary speech acts that the informants did were asking questions and curiosity about the day, namely, Friday to carry out Friday prayers.

The speech uttered by the informant in data (6) was carried out when the informant took rambutan fruit and some rambutan fell from his grasp then the remaining rambutan in his hand was stored on the table. The informant was disappointed and then said loba deui ... iya ... eh ... 'a lot more ... yes ... eh ...' while opening and pressing his hands that were thrust forward with a asking expression and took back the scattered rambutan. Then his wife said: "Just use a bowl, okay, so it doesn't fall." The informant said yes but his gesture shook his head. Informants often did inappropriate gestures like this. Informants sometimes say no with a nodding gesture. Emphasis on the illocation expressed by the informant was a request to a speech partner.

During the Covin-19 pandemic, informants often forgot to wear masks when going outside the house, resulting in a conversation between the informant and his wife, as follows: (7) Is: don't forget to wear a mask 

later.'

In: Heueuh... eh...eh... engke... 'Yes... eh... eh...

The informant nodded by saying heueuh then thought and said... eh... eh... while taking a mask but he did not wear it then shook his head and said engke 'later' holding the mask in his hand as he walked to the door and then came out. Outside, just use a mask. The purpose of the informant's speech act was to promise to use a mask but later use it after leaving the house. The emphasis of the illocutionary gesture that the informant made was agreeing to wear a mask.

Data (8) informants are eating mangoes with their son-in-law. Then while eating the mango and then holding the fork forward, the informant spoke: ieu... aya iеu... aya ieu 'in... 'this... there's this... there's this on...." While pointing back and getting up from his seat to approach his wife. Then the informant raised his right hand and twisted it around. His wife responded by saying "mango tree?" The informant nodded in agreement and his face looked at his son-in-law. The meaning of the communication uttered by the informant was: Are these mangoes picked from trees in Bogor? Here, the partner said, he was confused with the gesture displayed by the informant so that the partner did not answer. Because he wanted to emphasize the meaning of his utterance, the informant got up from his seat and approached his wife to explain the meaning of his utterance through the gesture he demonstrated. The expression of satisfaction can be seen on the face of the informant when his wife mentions "mango tree". The illocutionary gesture displayed by the informant is in the form of an illocutionary pressure from a questioning speech.

Data (9) shows that the informant's gesture is difficult to interpret by his speech partner. The informant walked into the family room pointing to the cupboard and said Mah... The informant brought his right hand into a fist and then put it on his nose and then his hand was rotating while saying again... mah... lap pel 'mom...mop'. Because his wife did not respond, the informant stepped into the cupboard and took a tissue. Then his wife answered... oh tissue? Have a real mop. The informant nodded as he left. Sometimes the informant's intent in communicating could not be understood by the speech partner, even though the gesture displayed was quite a lot. At this stage the informant always uses illocutionary speech acts by taking the initiative to do everything he says. Emphasis of illocutionary gestures by the informant is a request.

\subsection{Findings}

The findings were that when communicating collaboratively, the informant was able to negotiate an explanation to the speech partner using an interaction strategy, namely gesture. When making movements, the informants tend to be silent and think hard. The silence that this informant does is called silence. The informant made a silent silence because he forgot the word he wanted to say. According to Aitchison (1997), in general, people are quiet for a while, either for breathing or for other purposes. When talking, the silence for taking a breath is not much only about $5 \%$. Meanwhile, according to Dardjowidjojo (2008) there are several reasons why people are silent. First, because he has already started with his utterance, but in fact he is not ready to look for words or words to continue his utterance; second, because he forgot the words he needed. Therefore, he must "seek" it to continue speaking; and third, he must be very careful in his choice of words so that the effect is not, for example, horrendous.

Even though there was a gesture strategy, the informant's communicative intent in producing the utterance was not clearly conveyed. According to Cummings (2009), to determine the communicative intent behind indirect speech the listener must be able to determine that the literal meaning of the utterance cannot possibly describe the meaning desired by the speaker in a particular context. In a normal scenario, the interpretation process starting from the literal meaning of the utterance combined with the salient aspects of the context will lead the listener to the meaning desired by the speaker. Of course, in people with broca aphasia who experience pragmatic disorders this normal scenario is not suitable.

The next finding was that the informants carried out the language process by combining verbal and nonverbal language. Although the informants' strategies in language used verbal and non-verbal language, the meaning of their utterances was often not understood by the speech partner. This is in accordance with Mahasena (2016) arguing that verbal and non-verbal expression disorders are often found in sufferers of aphasia caused by strokes. Stroke is a blood circulation disorder in the brain which, apart from causing paralysis, also affects speech-smallpox when a stroke attacks the left hemisphere.

Indah (2017) adds that abnormal hemisphere asymmetry in people with Broca aphasia can complicate language functions, such as pragmatic functions, semantic functions, phonological functions and nonverbal communication functions. Furthermore, Indah (2017) said that post-stroke aphasia has an impact on speech disabilities. Sufferers often rely on non-verbal communication using body parts (gestural). Conversely, stroke sufferers better understand other people's speech when using a combination of verbal and non-verbal expressions.

\subsection{Analysis Results}

According to Xu, Gannnon, Emmacorey, Smith, and Braun (2009) gesture processing is carried out in brain 
regions, such as in the Broca area and Wernicke's area, which are also used by speech and sign language. This can be seen also when the informant tries to communicate, in addition to using verbal speech acts, also nonverbally in the form of gestures. Because the lesions suffered by the informants were in the left hemisphere, in the Broca area, the gestures they produced were mostly not in accordance with the informant's expected intentions, for example those that should have pointed to the west, the informants instead pointed to the south. This shows that informants are not only disabled in verbal language but also in nonverbal language or gestures.

In the case of illocutionary gestures, the informant has carried out the speech act according to the intended purpose, namely what the informant said was done immediately, in the hope that his speech could be understood by his speech partner. The informant carried out the strategy in two ways, namely unifying body actions in the form of movements of the hands, feet, and facial expressions with non-grammatical verbal language. The illocutionary gestures performed by the informants were notifications, requests, complaints, wishes.

In the process of compiling and understanding through linguistic codes, mental elements such as thoughts, associations, and experiences cannot be ignored. The understanding of words can also be interpreted as a marker of the form of an idea but because language can be an instrument of thought that refers to a certain atmosphere or reality, the existence of words that mark the shape of the idea is of course not in the structure of sound, structure of form, and structure of meaning but also intent. It is as if these things are neglected in the informant's linguistic production because sometimes the idea before being uttered is lost in his memory.

\section{CONCLUSION}

Language disorders can be more complex than mere speech disorders because language disorders involve language production disabilities and communication difficulties for those with Broca's aphasia. As experienced by informants who failed to apply the language skills they had acquired to communicate.

Broca's aphasia can cause disruption to speech planning and expression. The sentences produced by the informant were broken, he spoke haltingly, and was full of silence, as in speech rek ...itu ...ieu. This is because the word tool is also disturbed, so the pronunciation is often not clear. In addition, informants often forget to convey ideas that come out of their mental lexicon. Informants have difficulty finding the right words and difficulty remembering so that gestures are used as a language strategy.
The injury to the informant's brain, which was caused by the rupture of a blood vessel in the area of Broca, caused pathological symptoms. This pathological symptom can be distinguished from stuttering caused by a psychological disorder so that it results in an irregularity in speech, as in speech teu...leungit $n u$ pangalengan. For this reason, informants make communication strategies using nonverbal language, namely gestures.

Here the most obvious means of showing illocutionary stress is a type of expression dominated by gestures, which sometimes between verbal speech acts and gestures do not match the meaning. Illocutionary gestures are the main requirement for informants to show their existence in interacting. The hope is that the utterances conveyed can be understood by his speech partners. For this purpose, the informants made strategies by including gestures in speaking and acting.

Abnormalities in the structure and volume of the hemispheres result in communication disorders which become the main obstacle for people with aphasia. This has an impact on the informant's social skills, such as when the informant asks for tissue by using various gestures, but still the meaning is not conveyed to the partner, he said.

\section{REFERENCES}

Aitchison, J. (1997). Words in the Mind: An Introduction to the Mental Lexicon. Oxford: Blackwell.

Berthier, M. L., Dávila, G., García-Casares, N., \& Moreno-Torres, I. (2014). Post-stroke aphasia. In T. A. Schweizer \& R. L. Macdonald (Eds.), The behavioral consequences of stroke (pp. 95-117, Chapter 6). New York, NY: Springer

Cresswell, J. W. (1998). Research design: Qualitative \& quantitative approaches. London: SAGE Publicational.

Cummings, L. (1999). Pragmatics: A multidisciplinary perspective. New York: Oxford University Press Inc.

Cummings, Louise. (2009). Clinical pragmatics. England: Cambridge University Press.

Dardjowidjojo, S. (2008). Psycholinguistics: An introduction to understanding human language. Jakarta: Indonesian torch foundation.

Febryanto, D., Retnaningsih, \& Handayani, F. (2019). Early detection of acute stroke patients' aphasia: Analytic review. Journal of Medical Surgical Nursing, 2(2), 1-5. 
Fitri, F. I., \& Lastri, D. M. (2019). Features of chronic aphasia syndrome and its changes post therapy. The Journal of Medical School (JMS), 53(3) 125-132.

Goodglass, H., \& Kaplan, E. (1972). Boston aphasia examination. Philadelphia: Lea \& Febiger.

Hancock, D. R., \& Algozzine, B. (2006). Doing case study research: A practical guide for beginning researchers. New York and London: Teachers College Press.

Harianja, N. (2009). Language Relationship with the Brain. Journal of Unimed Bahas, (74). DOI: https://doi.org/10.24114/bhs.v0i74TH\%20XXXVI. 2504

Indah, R. N. (2017). Language disorders introductory study. Malang: UIN- Maliki Press.

Johan, M., \& Suri, S. R. (2019). Speech disorders in children under 3 years a neurolinguistic study. Grammatica Journal, 5(il), 25-35. https://doi.org/10.22202/JG.2019.V5il.2291

Purnamawati, I., Ratnawati, \& Maulida, N. (2018). Phonological errors in Broca Postroke's aphasia in a psycholinguistic review. Basa Taka Journal, 1(1), 30-36.

Purnomo, Sengkey, and Damopolii. (2016). The incidence rate of aphasia in stroke at the medical rehabilitation installation RSUP Prof. Dr. R. D. Kandou Manado year 2015. Journal e-Clinic (eCL), $4(2)$.

Santoso, N. P., Andayani, \& Setiawan, B. (2014). Aphasia language rehabilitation: A year period on one individual with global aphasia. In L. A. Wahid, F. Fariyah, S. Ismail, \& M. I. A. Wahab (Eds.) The 9th International Conference on Language, Education, Humanities, and Inovation (pp. 177182). Osaka: Infobase Creation Sdn Bhd.

Skipper, J. I., Devlin, J. T., \& Lametti, D. R. (2017). The hearing ear is always found close to the speaking tongue: Review of the role of the motor system in speech perception. Brain and Language, 164, 77105. https://doi.org/10.1016/j.bandl.2016.10.004

Villard, S., \& Kiran, S. (2017). To what extent does attention underlie language in aphasia? Aphasiology, 31(10), $1226-1245$.

$\mathrm{Xu}$, G., Emmerorey, S., \& Braun (2009). Symbolic gestures and spoken language are processed by a common neural system. Proc NatL Acad Sci USA. 106 , 20664-20669. https://doi.org/10.1073/pnas.0909197106

Yule, G. (1996). Pragmatic. England: Oxford University Press. 